\title{
Orta ve Geçit Bölgelerine Uygun Gazal Boynuzu (Lotus corniculatus L.) Çeşitlerinin Geliştirilmesi
}

\author{
Yaşar KARADA $\breve{G}^{1}$ \\ Selahattin ÇINAR ${ }^{2}$ \\ Mahir ÖZKURT ${ }^{1}$ \\ Rüştü HATIIPOĞLU ${ }^{4}$ \\ Tahsin TAŞYÜREK ${ }^{3}$ \\ Sezai GÖKALP3
}

${ }^{1}$ Gaziosmanpaşa Üniversitesi, Ziraat Fakültesi, Tarla Bitkileri Bölümü, Tokat

${ }^{2}$ KTMU Ziraat Fakültesi Kırgizistan/ Kilis 7 Aralık Üniversitesi, TBMYO Kilis

${ }^{3}$ Orta Karadeniz Geçit Kuşağı Tarımsal Araştırma İstasyonu Müdürlügü̈, Tokat

${ }^{4}$ Çukurova Üniversitesi, Ziraat Fakültesi, Tarla Bitkileri Bölümü, Adana

$\triangle$ : scinar01@hotmail.com

Geliş (Received): 02.11.2017

Kabul (Accepted): 15.12.2017

\begin{abstract}
ÖZET: Bu araştırma, 2013-2015 yılları arasında Tokat ve Sivas ekolojik koşullarında gazal boynuzu (Lotus corniculatus L.) çeşit adayının ot verimi ve ot kalitesini belirlemek amacıyla yürütülmüştür. Araştırmada, bir çeşit adayı ve iki çeşit materyal olarak kullanılmıştır. Denemeler iki lokasyonda (Tokat Orta Karadeniz Geçit Kuşağı Tarımsal Araştırma İstasyonu Müdürlüğü, Sivas-Şarkışla Yem Bitkileri Üretim İstasyonu), dört tekrarlamalı, tesadüf blokları deneme desenine uygun olarak yürütülmüştür. Araştırmanın sonuçları, incelenen çeşit adayı ve çeşitlerin ot verimlerinin önemli derecede farklılık gösterdiğini ortaya koymuştur. İki yıllık ortalamalara göre Tokat ve Sivas lokasyonunda sırasıyla en yüksek bitki boyu $(56.2,54.7 \mathrm{~cm})$, yaş ot verimi $(5010.5,2855.9 \mathrm{~kg}$ da-1), kuru ot verimi (1234.5, 847.2 kg da-1) ve ham protein verimi $(232.1,159.3 \mathrm{~kg}$ da-1) çeşit adayında saptanmıştır. Geliştirilen çeşit aday1 2016 yılı içerisinde tescil edilmek üzere TTSM'ye sunulmuştur.

Anahtar Kelimeler: Gazal boynuzu, bitki boyu, ham protein oranı, verim
\end{abstract}

\section{Development of Birds Foot Trefoil Cultivar for the Middle and Transition Regions of Turkey}

ABSTRACT: This study was carried out to determine the hay yield of cultivar candidate of birds foot trefoil under Tokat and Sivas ecological conditions during the years of 2013-2015. In the study, one cultivar candidate and two cultivars of birds foot trefoil were used as plant material. The field trial was designed according to a randomized block design with four replications in the research areas of Central Black Sea Transition Zone Agricultural Research Institute Directorate in Tokat and in Sivas-Sarkisla. Results of the study showed that the materials tested were significantly different in hay yield and quality. The cultivar candidate was the superior in hay yield. From the results of the study, it was concluded that cultivar candidate could be submitted to the TTSM for registration.

Key Words: Birds foot trefoil, plant height, crude protein ratio, hay yield

\section{GíRIŞ}

Hayvan besleme amaciyla kullanılan bitkilerin büyük bir kısmını baklagiller oluşturmaktadır. Baklagil yem bitkileri çayır meralarda doğal olarak yetişmekte ve hayvanların kaba yem ihtiyacını karşılamada önem taşımaktadırlar. Baklagil yem bitkilerinin besin değerleri ve hayvanlara yarayışlılıkları daha yüksektir. Baklagil yem bitkileri protein, vitamin ve minerallerce zengindir. Ayrıca baklagil yem bitkileri bal özü bitkisi olarak arıcılık da önem taşırlar. Aynı zamanda baklagil yem bitkileri, gerek meralarda gerekse tarım arazilerinde, aynı ortamda yaşadıkları bitkiler için önemli bir azot kaynağıdırlar.

Mera tesislerinde kullanılan tür ve çeşitlerin tohumların genel olarak yurt dışından ithal edilmekte ve milyonlarca dolar döviz ödenmektedir. Yurtdışından ithal edilen mera türlerinin miktarını net olarak belirten bir kayıt olmamasına rağmen ithal edilen yem bitkisi, çim ve çayır otu tohumluk miktarını gösteren veriler elde mevcuttur. 2002 yilında yem bitkisi, çim ve çayır otu ithalatı tohumluk miktarı 2.534 ton iken ithal edilen miktar yıllar içerisinde artmış 2010 yılında 4.627 tona, 2016 yılında ise 11.152 tona ulaşmıştır. Belirtilen bu tohumluk miktarının parasal değeri 2002 yılında
3.473.000, 2010 y1linda 8.670.000 \$, 2016 y1linda ise 20.683.000 \$' dir (GTHB, 2017). Ayrica ithal edilen bu tohumların kullanıldıkları alanları ekolojik koşullarına tam olarak adapte olamadıkları için çoğu kez mera tesis çalışmaları başarısız olmuştur.

Kaba yem açığının kapatılmasında meralar önemli bir yere sahiptir. Mera ıslahında kullanılmak üzere çok yıllık buğdaygil ve baklagil yembitkisi çeşitlerinin islah edilmesi ve bunların tohumlarının yeterli miktarda üretilmesi ile bir gen merkezi olan ülke kaynaklarından yerinde kullanım sağlanmış olacak ve ithalat yoluyla ülke dışına gitmekte olan kaynak kaybı önlenecektir.

Gazal boynuzu kurağa ve soğuğa dayanıklı, asitlik ve nem yönünden çok farklı toprak yapısına uyum gösteren, hayvanlar tarafindan sevilerek otlanan, şişirme özelliği olmayan, tohum dökme özelliği nedeniyle meralarda kendini kolayca yenileyebilen, otlatma amacıyla çayır salkımotu, kılçıksız brom, domuz ayrı̆̆ ve çayır kelp kuyruğu ile iyi bir karışım oluşturan iyi bir mera bitkisidir (Açıkgöz, 2001)

$\mathrm{Bu}$ araştırma ile orta ve geçit bölgelerine uygun, gazal boynuzu çeşit adayının ot verimi ve kalitesinin belirlenerek tescile sunulması amaçlanmıștır. 


\section{MATERYAL ve YÖNTEM:}

$\mathrm{Bu}$ araştırma, 2013 - 2015 yılları arasında Orta Karadeniz Geçit Kuşağı Tarımsal Araştırma İstasyonu Müdürlüğü'nün Tokat ve Sivas-Şarkışla'da bulunan deneme alanlarında yürütülmüştür. Denemelerde Sivas ve Tokat meralarından toplanan gazal boynuzu popülasyonlarından toptan seleksiyon yöntemi ile selekte edilerek geliştirilen 20 klondan oluşan bir adet gazal boynuzu çeşit adayı ile Goldia ve Leo çeşitleri materyal olarak kullanılmıştır.

Gaziosmanpaşa Üniversitesi Ziraat Fakültesi Toprak Analizi Laboratuarında yapılan analiz sonuçlarına göre her iki deneme alanı toprakları; killi tınlı, tuzsuz, hafif alkali, bitkiler tarafından alınabilir fosfor ve potasyum yönünden zengin, organik madde ve kireç bakımından orta düzeyde bir toprak özelliğine sahiptir (Aydeniz ve Brohi, 1991). Meteoroloji Genel Müdürlüğü verilerine göre, araştırmanın yürütüldüğü yıllar ve uzun yıllar aylık sicaklık ortalaması Tokat lokasyonunda, 12.2, 13.4 ve $12.5^{\circ} \mathrm{C}$, Sivas lokasyonunda; $9.0,10.2$ ve $9.3^{\circ} \mathrm{C}$, aylık toplam yağış miktarı Tokat lokasyonunda 267.5, 399.3 ve $443.7 \mathrm{~mm}$, Sivas lokasyonunda $242.3,312.3$ ve 385.5 $\mathrm{mm}$ ve ortalama nispi nem oranı ise Tokat lokasyonunda, \% 66.4, \% 68.6 ve $\%$ 62.5, Sivas lokasyonunda ise $\% \quad 63.4,62.0$ ve 62.3 olarak kaydedilmiştir. Buna göre deneme yıllarının uzun yıllardan daha az yağışlı geçtiğini söyleyebiliriz.

Çeşit adayı ve çeşitlerin her birisi $40 \mathrm{~cm}$ aralıklı $5 \mathrm{~m}$ uzunluğundaki 8 sıradan oluşan parsellere ekilmiştir.
Ekimde tohumluk miktarı $1.0 \mathrm{~kg} \mathrm{da}^{-1}$ olarak alınmış ve ekim öncesi parsellere $3 \mathrm{~kg} \mathrm{da}^{-1}$ saf azot, $5 \mathrm{~kg} \mathrm{da}^{-1}$ saf fosforlu gübre uygulanmıştır (Anonim, 2001). Denemeler her iki lokasyonda 4 tekrarlamalı, tesadüf blokları deneme desenine uygun olarak kurulmuştur. Hasat; başaklanma başlangıcında yapılmıştır. Hasatta her parselde yanlardan birer sıra ve parsel başı ile sonundan 0.5 m'lik kısım kenar tesiri olarak biçilip atıldıktan sonra, geriye kalan $4 \mathrm{~m}$ uzunluğundaki 6 sıra biçilmiştir. 2013 y1lı tesis yılı olduğundan dolayı kök gelişimi amacıyla herhangi bir hasat yapılmamıştır. Her iki yılda da Tokat lokasyonunda üç, Sivas lokasyonunda ise ikişer biçim yapılmıştır.

Her parselde; bitki boyu, yaş ot verimi, kuru ot verimi ve ham protein oran1, Anonim (1995), Anonim (2001) ve Şehirali (2002) tarafından açıklanan yöntemlere göre saptanmıştır. Araştırmadan elde edilen verilerin ddeğerlendirilmesinde, MSTAT-C istatistik paket programı kullanılarak tesadüf blokları deneme desenine uygun olarak varyans analizi uygulanmıştır. Varyans analizi sonuçlarına göre istatistiksel olarak önemli çıkan faktör ortalamaları LSD testi ile karşılaştırılmıştır (Düzgüneş ve ark. 1987).

\section{ARAŞTIRMA SONUÇLARI ve TARTIŞMA Bitki Boyu:}

Araştırmada incelenen çeşit adayı ve çeşitlerin bitki boyu ortalamaları Çizelge 1'de verilmiştir

Çizelge 1. Araştırmada incelenen gazal boynuzu materyalinde bitki boyu ortalamaları $(\mathrm{cm})$

\begin{tabular}{|l|c|c|c|}
\hline \multirow{2}{*}{ Çeşit adayı ve çeşitler } & \multicolumn{3}{|c|}{ Ana Sap Uzunluğu (cm) } \\
\cline { 2 - 4 } & \multicolumn{3}{|c|}{ Tokat Lokasyonu } \\
\cline { 2 - 4 } & $\mathbf{2 0 1 4}$ & $\mathbf{2 0 1 5}$ & Ortalama \\
\hline Çeşit Adayı & $53.6 \mathrm{a} *$ & $58.7 \mathrm{a}$ & $56.2 \mathrm{a}$ \\
\hline Leo & $43.9 \mathrm{~b}$ & $52.3 \mathrm{c}$ & $58.1 \mathrm{c}$ \\
\hline Goldia & $52.3 \mathrm{ab}$ & $55.7 \mathrm{~b}$ & $52.0 \mathrm{~b}$ \\
\hline Ortalama & $49.9 \mathrm{~B}$ & $55.6 \mathrm{~A} * *$ & $54.7 \mathrm{a}$ \\
\hline \multicolumn{3}{|c|}{ Sivas Lokasyonu } \\
\hline Çeşit Aday1 & & 55.9 & $52.2 \mathrm{~b}$ \\
\hline Leo & $53.5 \mathrm{a} *$ & 54.2 & $52.5 \mathrm{~b}$ \\
\hline Goldia & $50.1 \mathrm{~b}$ & 54.6 & 53.1 \\
\hline Ortalama & $50.3 \mathrm{~b}$ & $54.9 \mathrm{~A}$ & \\
\hline
\end{tabular}

*Aynı sütun içerisinde benzer harf ile gösterilen ortalamalar, LSD testine göre, $\mathrm{P} \leq 0,05$ hata sınırları içerisinde birbirlerinden farksızdır. **Aynı satır içerisinde benzer harf ile gösterilen ortalamalar, $\mathrm{P} \leq 0,01$ hata sınırları içerisinde birbirlerinden farksızdır.

Çizelge 1'de görüldüğü üzere her iki lokasyonda çeşit adayı ve çeşitler ile yıllar bitki boyunda istatistiki olarak önemli farklar yaratmıştır. Her iki lokasyonda en yüksek bitki boyu çeşit adayında belirlenmiştir. Tokat lokasyonunda ortalama bitki boyu $52.8 \mathrm{~cm}$ iken Sivas lokasyonunda $53.1 \mathrm{~cm}$ olarak gerçekleşmiştir. Gazal boynuzunda bitki boyunu, Sağlamtimur ve ark. (1986) 37.5-70.4 cm, Douglas ve ark. (1996), $43.5 \mathrm{~cm}$, Drobna (2010) 16.0-37.0 cm, Dal (2011) 50.0-90.7 cm olarak bildirmişlerdir. Araştırmadan elde edilen bulgular Sağlamtimur ve ark. (1986), Dal (2011) ile uyumlu, Douglas ve ark. (1996), Drobna (2010) ile uyumlu değildir. Bunun nedeninin ekoloji, bakım ve çeşit farklılığından kaynaklandığını söyleyebiliriz.

\section{Yaş Ot Verimi:}

Araştırmada incelenen gazal boynuzu materyalinde yaş ot verimleri ortalama değerleri Çizelge 2'de verilmiştir. 
Çizelge 2. Araştırmada incelenen gazal boynuzu materyalinde yaş ot verimi ortalamaları $\left(\mathrm{kg} \mathrm{da}^{-1}\right)$

\begin{tabular}{|l|c|c|c|}
\hline \multirow{2}{*}{ Çeşit adayı ve çeşitler } & \multicolumn{3}{|c|}{ Tokat Lokasyonu } \\
\cline { 2 - 4 } & $\mathbf{2 0 1 4}$ & $\mathbf{2 0 1 5}$ & Ortalama \\
\hline Çeşit Adayı & $4851.6 \mathrm{a}^{*}$ & $5169.4 \mathrm{a}$ & $5010.5 \mathrm{a}$ \\
\hline Leo & $3498.5 \mathrm{~b}$ & $4091.1 \mathrm{~b}$ & $3794.8 \mathrm{~b}$ \\
\hline Goldia & $4515.6 \mathrm{a}$ & $4954.4 \mathrm{a}$ & $4735.0 \mathrm{a}$ \\
\hline Ortalama & $4288.6 \mathrm{~B}^{* *}$ & $4738.3 \mathrm{~A}$ & 4513.5 \\
\hline \multicolumn{4}{|c|}{ Sivas Lokasyonu } \\
\hline Çeşit Aday1 & $2500.8 \mathrm{a}^{*}$ & $3210.9 \mathrm{a}$ & $2855.9 \mathrm{a}$ \\
\hline Leo & $2229.4 \mathrm{~b}$ & $3172.0 \mathrm{a}$ & $2700.7 \mathrm{~b}$ \\
\hline Goldia & $2115.4 \mathrm{~b}$ & $2621.9 \mathrm{~b}$ & $2638.7 \mathrm{~b}$ \\
\hline Ortalama & $2282.0 \mathrm{~B} * *$ & $3001.6 \mathrm{~A}$ & 2641.8 \\
\hline
\end{tabular}

${ }^{*}$ Aynı sütun içerisinde benzer harf ile gösterilen ortalamalar, LSD testine göre, $\mathrm{P} \leq 0,05$ hata sınırları içerisinde birbirlerinden farksızdır. **Aynı satır içerisinde benzer harf ile gösterilen ortalamalar $\mathrm{P} \leq 0,01$ hata sınırları içerisinde birbirlerinden farksızdır.

Çizelge 2'de görüldüğü üzere her iki lokasyonda çeşit adayı ve çeşitler ile yıllar, yaş ot verimlerinde istatistiki olarak önemli farklar yaratmıştır. Her iki lokasyonda en yüksek yaş ot verimi çeşit adayında saptanmıştır. Tokat lokasyonunda ortalama yaş ot verimi $4513.5 \mathrm{~kg} \mathrm{da}^{-1}$ iken Sivas lokasyonunda $2641.8 \mathrm{~kg} \mathrm{da}^{-1}$ olarak gerçekleşmiştir.

Gazal boynuzunda yaş ot verimini, Çınar ve ark. (2012) $2641-3166 \mathrm{~kg} \mathrm{da}^{-1}$, Özcan ve ark. (2013) 395.2-1555.2 $\mathrm{kg} \quad \mathrm{da}^{-1}$ olarak bildirmişlerdir. Araştırmadan elde edilen yaş ot verimi değerleri Çınar ve ark. (2012) ile uyumlu, Özcan ve ark. (2013) ile uyumlu değildir. Bunun nedeninin ekoloji, bakım ve çeşit farklılığından kaynaklandığını söyleyebiliriz.

\section{Kuru Ot Verimi:}

Araştırmada incelenen otlat ayrı̆̆ı materyalinde kuru ot verimleri ortalama değerleri Çizelge 3'de verilmiştir. Çizelge 3'de görüldüğü üzere her iki lokasyonda çeşit adayı ve çeşitler ile yıllar, kuru ot verimlerinde istatistiki olarak önemli farklar yaratmıştır. Her iki lokasyonda en yüksek kuru ot verimi çeşit adayında saptanmıştır. Tokat lokasyonunda ortalama kuru ot verimi $1133.1 \mathrm{~kg} \mathrm{da}^{-1}$ iken Sivas lokasyonunda $764.1 \mathrm{~kg} \mathrm{da} \mathrm{da}^{-1}$ olarak gerçekleşmiştir

Çizelge 3. Araştırmada incelenen gazal boynuzu materyalinde kuru ot verimi ortalamaları $\left(\mathrm{kg} \mathrm{da}^{-1}\right)$

\begin{tabular}{|l|c|c|c|}
\hline \multirow{2}{*}{ Çeşit adayı ve çeşitler } & \multicolumn{3}{|c|}{ Tokat Lokasyonu } \\
\cline { 2 - 4 } & $\mathbf{2 0 1 4}$ & $\mathbf{2 0 1 5}$ & Ortalama \\
\hline Çeşit Adayı & $1168.8 \mathrm{a}^{*}$ & $1300.2 \mathrm{a}$ & $1234.5 \mathrm{a}$ \\
\hline Leo & $961.4 \mathrm{~b}$ & $1073.1 \mathrm{c}$ & $1017.3 \mathrm{~b}$ \\
\hline Goldia & $1120.1 \mathrm{a}$ & $1175.1 \mathrm{~b}$ & $1147.6 \mathrm{a}$ \\
\hline Ortalama & $1083.4 \mathrm{~B}^{* *}$ & $1182.8 \mathrm{~A}$ & 1133.1 \\
\hline \multicolumn{3}{|c|}{ Sivas Lokasyonu } \\
\hline Çeşit Adayı & $735.2 \mathrm{a}^{*}$ & $959.1 \mathrm{a}$ & $847.2 \mathrm{a}$ \\
\hline Leo & $651.0 \mathrm{~b}$ & $867.5 \mathrm{a}$ & $759.3 \mathrm{~b}$ \\
\hline Goldia & $624.2 \mathrm{~b}$ & $747.6 \mathrm{~b}$ & $685.9 \mathrm{c}$ \\
\hline Ortalama & $670.1 \mathrm{~B} * *$ & $858.1 \mathrm{~A}$ & 764.1 \\
\hline
\end{tabular}

*Aynı sütun içerisinde benzer harf ile gösterilen ortalamalar, LSD testine göre, $\mathrm{P} \leq 0,05$ hata sınırları içerisinde birbirlerinden farksızdır. **Aynı satır içerisinde benzer harf ile gösterilen ortalamalar $\mathrm{P} \leq 0,01$ hata sınırları içerisinde birbirlerinden farksızdır.

Çizelge 4. Araştırmada incelenen gazal boynuzu materyalinde ham protein oranı ortalama değerleri (\%)

\begin{tabular}{|l|c|c|c|}
\hline \multirow{2}{*}{ Çeşit adayı ve çeşitler } & \multicolumn{3}{|c|}{ Tokat Lokasyonu } \\
\cline { 2 - 4 } & $\mathbf{2 0 1 4}$ & $\mathbf{2 0 1 5}$ & Ortalama \\
\hline Çeşit Aday1 & 18.8 & 19.8 & 19.3 \\
\hline Leo & 18.4 & 19.1 & 18.8 \\
\hline Goldia & 18.5 & 19.0 & 18.8 \\
\hline Ortalama & $18.6 \mathrm{~B}^{* *}$ & $19.3 \mathrm{~A}$ & 19.0 \\
\hline \multicolumn{3}{|c|}{ Sivas Lokasyonu } \\
\hline Çeşit Adayı & 18.9 & 19.5 & 19.2 \\
\hline Leo & 18.4 & 19.0 & 18.7 \\
\hline Goldia & 18.6 & 18.8 & 18.7 \\
\hline Ortalama & $18.6 \mathrm{~B}^{* *}$ & $19.1 \mathrm{~A}$ & \\
\hline
\end{tabular}

**Aynı satır içerisinde benzer harf ile gösterilen ortalamalar $\mathrm{P} \leq 0,01$ hata sınırları içerisinde birbirlerinden farksızdır. 
Gazal boynuzunda kuru ot verimini, Avcığlu ve ark. (1991) 999.0-1230.0 $\mathrm{kg} \mathrm{da}^{-1}$, Tan ve ark. (1991) $602.0 \mathrm{~kg} \mathrm{da}^{-1}$, Parlak (2005) 772.0-791.0 kg da-1 olarak bildirmişlerdir. Araştırmadan elde edilen kuru ot verimi değerleri Avcıŏlu ve ark. (1991), Parlak (2005) ile uyumlu, Tan ve ark. (1991) ile uyumlu değildir. Bunun nedeninin ekoloji, bakım ve çeşit farklılığından kaynaklandığını söyleyebiliriz.

\section{Ham Protein Orani:}

Araştırmada incelenen gazal boynuzu materyalinde ham protein oranı ortalama değerleri Çizelge 4'de verilmiştir.

Çizelge 4'de görüldüğü üzere çeşit ve çeşit adayları ham protein oranlarında istatistiki bir fark oluşturmamıştır. Ancak her iki lokasyonda çeşit ve çeşit adayları yıllarda istatistiki bir farklılık yaratmıştır.
Gazal boynuzunda ham protein oranını Karabulut ve ark. (2006) \% 15.0, Başaran ve ark. (2006) \% 17.9, Kaplan ve ark. (2009) \% 20.6, Kökten ve ark. (2009), \% 16.1 olarak bildirmişlerdir. Araştırmadan elde edilen ham protein oranı değerleri Kaplan ve ark. (2009) ile uyumlu Karabulut ve ark. (2006), Başaran ve ark. (2006), Kökten ve ark. (2009) ile uyumlu değildir. Bunun nedeninin ekoloji, bakım ve çeşit farklılığından kaynaklandığını söyleyebiliriz.

\section{Ham Protein Verimi:}

Araştırmada incelenen çeşit adayı ve çeşitlerin ham protein verimleri ortalama değerleri Çizelge 5'de verilmiştir.

Çizelge 5. Araştırmada incelenen gazal boynuzu materyalinde ham protein verimi ortalama değerleri $\left(\mathrm{kg} \mathrm{da}^{-1}\right)$

\begin{tabular}{|l|c|c|c|}
\hline \multirow{2}{*}{ Çeşit adayı ve çeşitler } & \multicolumn{3}{|c|}{ Tokat Lokasyonu } \\
\cline { 2 - 4 } & $\mathbf{2 0 1 4}$ & $\mathbf{2 0 1 5}$ & Ortalama \\
\hline Çeşit Aday1 & $219.7 \mathrm{a}^{*}$ & $244.4 \mathrm{a}$ & $232.1 \mathrm{a}$ \\
\hline Leo & $180.7 \mathrm{c}$ & $201.7 \mathrm{c}$ & $191.2 \mathrm{c}$ \\
\hline Goldia & $210.6 \mathrm{~b}$ & $220.9 \mathrm{~b}$ & $215.7 \mathrm{~b}$ \\
\hline Ortalama & $203.7 \mathrm{~B}^{* *}$ & $222.4 \mathrm{~A}$ & 213.0 \\
\hline \multicolumn{3}{|c|}{ Sivas Lokasyonu } \\
\hline Çeşit Aday1 & $138.2 \mathrm{a}^{*}$ & $180.3 \mathrm{a}$ & $159.3 \mathrm{a}$ \\
\hline Leo & $122.4 \mathrm{~b}$ & $163.1 \mathrm{~b}$ & $142.7 \mathrm{~b}$ \\
\hline Goldia & $117.3 \mathrm{~b}$ & $140.5 \mathrm{c}$ & $128.9 \mathrm{c}$ \\
\hline Ortalama & $126.0 \mathrm{~B} * *$ & $161.3 \mathrm{~A}$ & 143.7 \\
\hline
\end{tabular}

*Aynı sütun içerisinde benzer harf ile gösterilen ortalamalar, LSD testine göre, $\mathrm{P} \leq 0,05$ hata sınırları içerisinde birbirlerinden farksızdır. **Aynı satır içerisinde benzer harf ile gösterilen ortalamalar, $\mathrm{P} \leq 0,01$ hata sınırları içerisinde birbirlerinden farksızdır.

Çizelge 5'de görüldüğü üzere her iki lokasyonda çeşit adayı ve çeşitler ile yıllar, ham protein verimlerinde istatistiki olarak önemli farklar yaratmıştır. Her iki lokasyonda da en yüksek ham protein verimi çeşit adayından elde edilmiştir. Ham protein verimi Tokat lokasyonunda ortalama $213.0 \mathrm{~kg} \mathrm{da}^{-1}$ iken Sivas lokasyonunda ise $143.7 \mathrm{~kg} \mathrm{da}^{-1}$ olarak gerçekleşmiştir. Ham protein verimi ham protein oranları ile kuru ot verimlerinden elde edilen bir değer olduğundan dolayı genel olarak kuru ot verimi ve ham protein oranı yüksek olan genotiplerin de ham protein verimi yüksek bulunmuştur.

Gazal boynuzunda ham protein verimlerini Barnet ve Posler (1983) $82.0 \mathrm{~kg} \mathrm{da}^{-1}$, Serin ve ark. (1997) 155.1 $\mathrm{kg} \mathrm{da}^{-1}$, Kökten ve ark. (2009) 102,9 kg da-1, Bayram ve

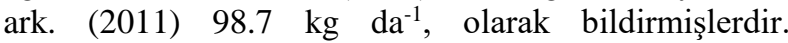
Araştırmadan elde edilen ham protein verimi değerleri Serin ve ark. (1997) ile uyumlu Barnet ve Posler (1983), Kökten ve ark. (2009), Bayram ve ark. (2011) ile uyumlu değildir. Bunun nedeninin ekoloji, bakım ve çeşit farklılığından kaynaklandığını söyleyebiliriz.

\section{SONUC}

Araştırma sonuçlarına göre; en yüksek bitki boyu, yaş ot verimi, kuru ot verimi ve ham protein verimi çeşit adayında belirlenmiştir. Çeşit adayının tescile sunulmasına karar verilmiştir.

\section{TEŞEKKÜR:}

$\mathrm{Bu}$ bildiri $113 \mathrm{O} 012$ nolu TÜBİTAK projesinden elde edilen verilerden hazırlanmıştır. Desteklerinden dolayı TÜBİTAK'a teşekkür ederiz.

\section{KAYNAKLAR:}

Açıkgöz E 2001. Yem Bitkileri, Uludağ Ünv. Güçlendirme Vakfı Yayın No:182 Bursa

Anonim 1995. The Determination Of Nitrogen According To Kjeldahl Using Block Digestion And Steam Distilation. Tecator Application Note An 300, Tecator Ab Sweden, P: 1-11

Anonim 2001. Tarımsal Değerleri Ölçme Denemeleri Teknik Talimatı. Buğdaygil Yem Bitkileri Tarımsal Değerler Ölçme Denemeleri. Tc. Tar. Ve Köy. Bak. Kor. Ve Kont. Gen. Müd. Toh. Tes. Ve Sertifikasyon Mer. Müd.

Avcioglu R, Akbar N, Soya H. ve Sabanc1 CO 1991. Ege Sahil Kuşağında Yapay Çayır- Mera Kurma Olanakları Üzerinde Araştırmalar. Türkiye 2. ÇayırMera ve Yem bitkileri Kongresi. 28-31 Mayıs 1991, İzmir, s:181-190. 
Aydeniz A, Brohi AR. 1991. Gübreler ve Gübreleme. C.Ü. Tokat Ziraat Fakültesi Yayınları, Yayın No. 10, Ders Kitab1 3, Tokat.

Bayram G, Budaklı Çarpıcı E ve Çelik N 2011. Bursa taban koşullarında suni mera tesisinde kullanılacak çok yıllık buğdaygil ve baklagil yem bitkileri karışımlarının belirlenmesi üzerine bir araştırma. IX. Tarla Bitkileri Kongresi, 12-15 Eylül, III. Cilt:16491655, Bursa (Sunulu Bildiri).

Çınar S, Hatipoğlu R, Avcı M, Aktaş A, Kökaşık FD 2012. Çukurova Taban Koşullarında Mera Tesisinde Kullanılabilecek Bazı Çok yıllık Sıcak Mevsim Buğdaygiller İle Baklagil Karışımlarının Yaş ve Kuru Ot Verimlerinin Belirlenmesi. Tarım Bilimleri Araştırma Dergisi, 5, 14-18.

Drobna J 2010. Morphological variation in natural populations of Lotus corniculatus in association to geographical parameters of collecting sites. Biologia Botany Section, 65, 213-218.

Douglas GB, Wills BJ, Pryor HN, Foote AG, Trainor KD 1996. Establishment of perennial legume species in drought-prone, North and South Island sites, Proceedings of the New Zealand Grassland Association, 58, 253-257.

Düzgüneş O, Kesici T, Kavuncu O, Gürbüz F 1987. Araştırma Ve Deneme Metodları, Ankara Üniv. Zir. Fak. Yayınları, No: 295, Ankara.

GHTB, 2017. www.tarim.gov.tr 27.11.2017

Hatipoğlu R. ve Avcioğlu R 2009.Gazalboynuzu Türleri, Baklagil Yembitkileri, (Avcioğlu, R., Hatipoğlu, R., Karadağ,Y Edit.) Cilt II. TÜGEM, Emre Basımevi, İzmir, s: 387-401

Karabulut A, Canbolat O, Kamalak A 2006. Effect of maturity stage on the nutritive value of birdsfoot trefoil (Lotus corniculatus L.) hays. Lotus Newsletter, 36 (1), 11-21.
Kaplan M, Atalay Aİ, Medjekal S 2009. Potential nutritive value of wild birdsfoot trefoil (Lotus corniculatus) plants grown in different sites. Livestock Research for Rural Development, 21 (7), 99-102.

Özcan G, Ateş S, Işı1k Ş, Kırbaş M, Güneş A, ve Aktaş A H 2013, Basit ve çoklu karışımlardan oluşan yapay meraların verim ve botanik kompozisyonları Türkiye 10. Tarla Bitkileri Kongresi, Konya.

Parlak 2005 Bazı Yapay Mera Karışımlarında Ekim Yöntemleri ve Azot Dozlarının Yem Verimi ve Kalitesine Etkileri Ankara Üniversitesi Fen Bilimleri Enstitüsü Tarla Bitkileri Anabilim Dalı 2005, 171 sayfa

Sağlamtimur T, Gülcan H, Tükel T, Tansı V, Anlarsal A E ve Hatipoğlu R 1986. Çukurova Koşullarında Yem bitkileri Adaptasyon Denemeleri. II. Baklagil Yem bitkileri. Ç.Ü.Ziraat Fakültesi Dergisi 1(3): 3751.

Serin Y, Gökkuş A, Tan M, Çomaklı B, ve Koç A 1997. Otlakiye amaciyla kullanılabilecek baklagil ve buğdaygil yem bitkileri ile bunların karışımlarının belirlenmesi. Tarla Bitkileri Merkez Araş. Enst. Der., 6; 15-26.

Şehirali S 2002. Tohumluk Ve Teknolojisi. Trakya Üniv. Tekirdağ Zir. Fak. Tarla Bit. Böl. Yenilenmiş 3. Bask1, İstanbul, $464 \mathrm{~S}$.

Tan M, Bakoğlu A, Koç A 1997. Gazal boynuzunda (Lotus corniculatus L.) toprak üstü bioması ve kimyasal kompozisyonun gelişme çağı içerisindeki değişimi. Türkiye 2. Tarla Bitkileri Kongresi, Samsun, Türkiye, 22-25 Eylül.

Tosun F 1979. Erzurum Şartlarında Bazı Gazalboynuzu Varyetelerinin Adaptasyonu ve Verim Denemesi. A.Ü. Ziraat Fakültesi Dergisi 10 (3-4): 83-89 